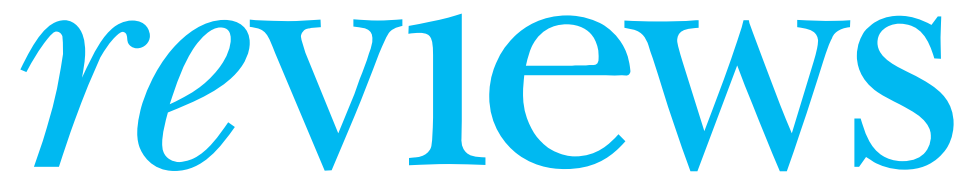

BOOKS • CD ROMS • ART •WEBSITES $\bullet$ MEDIA $\bullet$ PERSONAL VIEWS $\bullet$ SOUNDINGS

\section{George and Sam}

Charlotte Moore

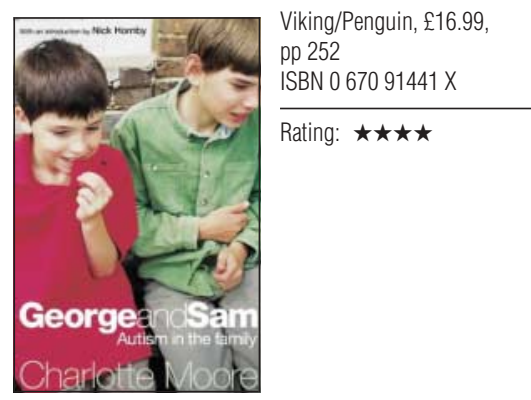

$\mathrm{H}$

aving seen a newspaper excerpt from Charlotte Moore's account of her autistic sons, some parents wrote to complain that she had neglected the "grittier realities" of life as a single parent caring for children with autism. In fact, the book reveals a household smeared with excrement, olive oil, and ketchup, and details all manner of bizarre behaviours. What seems to have rankled is that Moore describes her family in a positive and often humorous way, and that she does not seem to feel sorry for herself.
The truly distinctive feature of George and Sam is its author's lack of self pity. This outlook stands in marked contrast to that of the parents engaged in the campaign to blame their children's autism on the MMR (measles, mumps, and rubella) vaccine, who have received such widespread publicity. This campaign has nurtured parental self pity, expressed in an enduring rage against the drug companies, the medical establishment, indeed anybody who defends the vaccine. The quest for somebody to blame, for somebody to suffer as they have suffered, has driven the protracted-and now doomed-litigation against the MMR manufacturers.

While Moore deftly sidesteps the MMR controversy (though she does not believe that the vaccine was a factor in her sons' cases), she categorically rejects the notion that autism can be "cured." This does not mean that she recommends an attitude of resignation; far from it. She reports on the wide range of interventions she has tried on her boys, including diets and drugs, psychotherapy, and behaviour therapy, with varying degrees of success in alleviating some of the clinical features of their condition.
Finely observed, well researched, and elegantly written, George and Sam is full of insights into the mysteries of autism. Moore's appreciation of the physical beauty and "incorruptible innocence" of her sons will strike a chord with many parents. So too will her observation that "the people who get on best with autists are those who can put their own ego to one side." My wife often says that our autistic son "brings out the best in people."

Moore includes a brilliant survey of autistic tastes in videos and books, and fascinating reflections on the challenge of autism to theologians and on the problems posed by Christmas for families of autistic children. She also offers useful practical suggestions for doctors and teachers, for families, and-a generally neglected category-their friends.

"Acceptance is all," wrote Charlotte Moore in one of the newspaper columns from which this book originated. This simple, yet profound, message is what makes George and Sam such a valuable contribution to families affected by autism.

Michael Fitzpatrick general practitioner, London Fitz@easynet.co.uk

\section{Excerpts from a Family Medical Dictionary}

Rebecca Brown

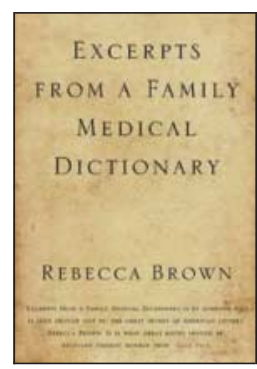

Granta, £10, pp 108 ISBN 1862076421

Rating: $\star \star \star \star$

$\mathrm{H}$ ow to write about the death of your mother? That is the burden Rebecca Brown admirably shoulders in this short and valuable memoir. Each pithy chapter is titled after a medical term, an ever serious litany that charts the downward spiral of a life.

Brown's mother was an active soul who rarely complained, a keen driver based in New Mexico who travelled across the vast spaces of American desert to visit her beloved family on the West Coast. One time she isn't up to it, she feels tired"her doctor had told her she needed rest." When she gets to the right team it turns out that she has metastatic gastric carcinoma: "Your mother is profoundly anemic," this new doctor said. Then he repeated, "profoundly."

Neither panegyric nor horror-show freak out, Brown's reportage of the subsequent medical events is never judgmental, the bad news given straight. Here she is after meeting the surgeon: "He said he couldn't be certain until they got the biopsy back, but 'the tumor was probably cancerous.' Then I was doing this thing with the words in my head. I said to myself, He didn't say she had cancer, he only said the tumor was probably cancerous and tumors can be taken out, I thought at exactly the same time. I was making all these fine, picky distinctions in my head."

Brown's eye on her own and others' reactions are unflinching: "When we came in (to the waiting room) everyone stared at her. The sick people looked healthy compared to her. They looked fantastic. I don't know if she knew how she looked. She smiled and some people tried to smile back, but most people looked away."

This is a dry eyed and balanced account written after the acute pain has subsided only to leave the blunt ache of loss. Brown's is a lean, laconic story where every word is squeezed out like a drip from a burette. Like Hemingway, like Carver, a simple prose style appears facile but is only achieved after much rewriting, much agonising. Brown's lapidary work is in this tradition and is complimentary to the difficult material.

It has been said with regards to bereavement that there is no language but the cry. Brown finds those elusive words. Essential reading for those involved in palliative care, and that's all of us.

John Quin consultant physician, Royal Sussex County Hospital, Brighton

John.Quin@bsuh.nhs.uk

Items reviewed are rated on a 4 star scale (4=excellent) 


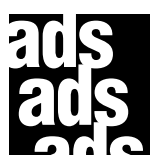

\section{The new tobacco?}

B arry Delaney, ex-owner of an advertising agency and now industry consultant, is still shocked by the UK ban on tobacco advertising, brought in on Valentine's Day last year. "I really didn't think it would happen in my lifetime," he says, despite being one of the first industry figures to oppose cigarette advertising.

But happen it did, and its effect is still reverberating. The victory has given campaigners the confidence to carry the fight over into other products that pose a threat to public health-notably junk food, alcohol, and cars.

Although no one will admit it publicly, reports suggest that concern is growing among advertising agency executives that the industry could be slapped with another statutory ban, this time on TV advertising of unhealthy food for children. The report on obesity of the House of Commons Select Committee on Health, published in May, stopped short of demanding an immediate ban on advertising targeted at children. But it said the food and advertising industries should be given three years' grace to change their policies.

At the same time, alcohol as well as fatty foods is regularly being referred to as "the new tobacco" in the trade press-so much so that the Advertising Association has voluntarily offered to tighten up regulations governing the advertising of alcohol in the wake of public angst about binge drinking and a linked rise in violence in city centres at weekends.

One Advertising Association insider was recently quoted as saying: "When you are staring down the barrel of a gun, it's more likely you'll set aside your differences. Just going on as we are is not an option."

However, Andrew Brown, the association's director general, doesn't take the position of the hunted prey. He singles out alcohol and fatty foods as vulnerable areas for further regulation, but believes that "serious and constructive" dialogue with the government is working. "To be frank, I don't think the government or Ofcom [the regulator for the UK communications industries] favour a ban on alcohol but do favour revisiting codes."

What could change? "I think the association with sex and alcohol is a whole area the industry could do something about. The code already forbids using anybody who is, or who appears to be, under the age of 26 . One of the areas that could be revisited is how people behave in these ads. So if you have somebody over 26 behaving in a "laddish" way that could have a particular

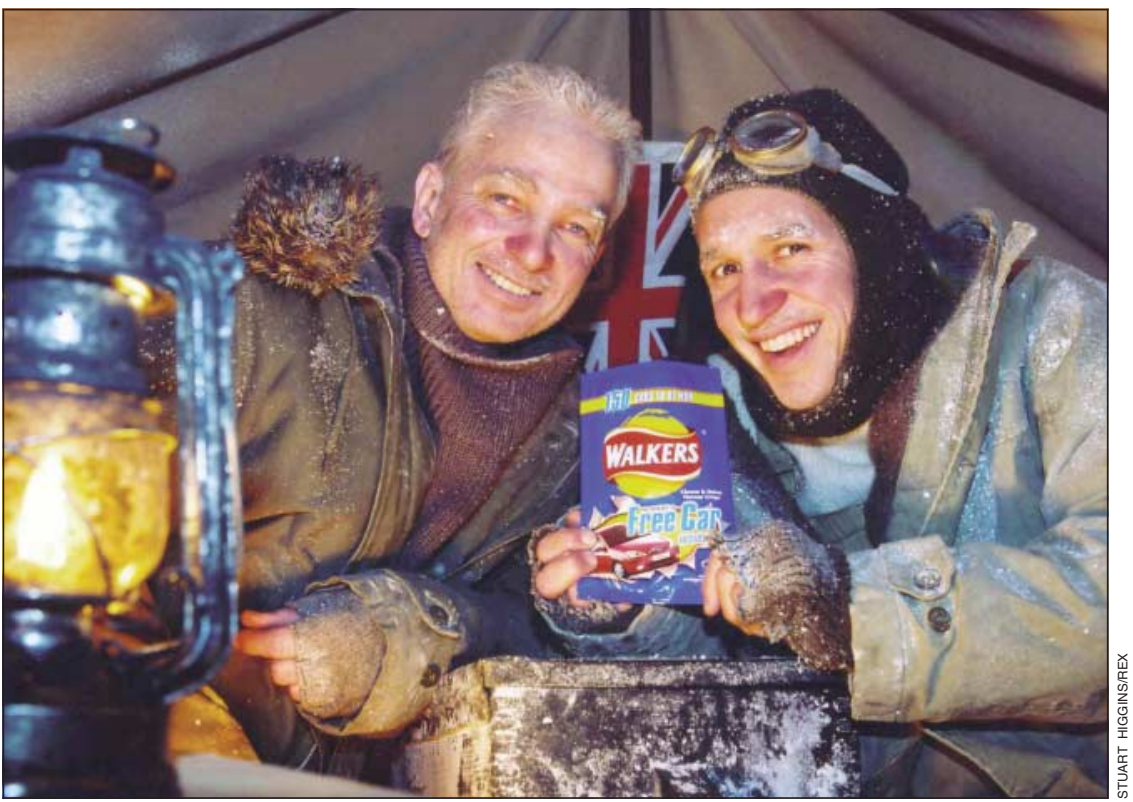

First smoking, then junk food: now advertising executives are wondering where public health campaigners will strike next

appeal to adolescents. A number of drink companies have tightened up their own internal rules."

Referring to the BMA, which has been the most prominent body to call for a ban on alcohol advertising, he politely says its arguments were "a standard response" with little evidence to back them up. "If you look at the expenditure figures in advertising, the heaviest area is in beers and spirits. But these sections are in decline. The least is spent in the area of white wine, but this is the area showing growth. The debate has raged about alcopops, but these products are in a big sales decline; it is a fashion that has had its day."

Barry Delaney adds that advertising products other than tobacco isn't intrinsically harmful. "Tobacco is quite distinct because it is the only legally available product that, if you use it as the manufacturers intend, it will do you some harm. With booze-another candidate for a banmillions of people use it and don't even get drunk. If you ban advertising on these products the world won't come to an end, but it will distract people from doing something more practical."

He says further regulation could see a renaissance in surrealist-style advertising, epitomised in the Silk Cut and Benson and Hedges commercials, but adds that most advertising is already quite sophisticated. "Big brands don't tend to promote the quality of their products, they just remind you that they are there. McDonald's seldom claims any nutritional value to their hamburgers, for example. So it's easy to comply with laws and regulations."

The basic dilemma for the advertising industry is that on one hand it is trying to convince businesses that advertising really does work, while on the other it is telling the government that advertising isn't as powerful as it thinks it is. One of the solutions currently being discussed is along the lines of the Portman Group's "responsible drinking" initiative, in order to pre-empt any government interference on advertising to children.

One of the agencies currently involved in brainstorming the problem is Abbott Mead Vickers BBDO, an agency that creates advertising for Guinness and also is responsible for the government's "Think!" road safety campaign. Its diverse range of clients shows how the power of advertising can be harnessed to good effect, says its chief executive Cilla Snowball. "The evidence from Sweden and Quebec suggests a ban on advertising to children would have no beneficial effect. The code could be improved, but the real answer to the problem lies in dealing with the factors that drive long term behavioural change. We are already making a start by working with food clients on the development and promotion of healthy eating and active lifestyle messages."

The mood of the press is such that banning advertising on certain products would be an easy electoral gain for the Labour government. A motion to support a ban on television advertising to children was quickly signed by 144 members of parliament.

A spokesman for the pressure group Sustain was dismissive of the advertising industry's claims that it was working in partnership with the government to improve health: "The industry has done nothing. I think they are canny and know the pressure won't just go away but they will fight tooth and nail. They strongly deny they are part of the problem, so how can they be part of the solution? Even if they did acknowledge weaknesses, the food industry is so competitive and so diverse that it would be unrealistic to think that they could come together as one voice."

Rebecca Coombes freelance journalist, London RebeccaCoomes@aol.com 


\section{Wasting time with people}

"W

aste time with people," advised the African bishop with a smile. "You Europeans are always concerned about projects and budgets. The African does not worry about them-just waste time with people." He gave me this advice in 1996 shortly before I came out to work in Uganda. Since then his words have kept coming back to me, and I reflect on their truth and wisdom and how difficult it has been for me, as someone with European values and attitudes, to apply them.

I supervise eight rural health centres in the west of Uganda, scattered among the foothills of the Rwenzori mountains. I love driving out on winding dirt tracks, past steep fields planted with cassava and coffee, and dodging the ubiquitous goats, to an isolated health centre run by two or three nurses and community health workers, a centre with few drugs but many patients. The dedication and perseverance of the staff are a real inspiration to me.

Health centres in Uganda, even those built and run entirely by Ugandans, are based on a European model. As in the United Kingdom health centres in Uganda require certain ways of operating, such as staffing structures, duty rosters, plans, budgets, and so on, having their roots in certain cultural values and norms, such as how we
Africans are being lured away from their own traditional medicine to Western systems burns and peptic ulcers, and papaya for cleaning dirty wounds, treating worm infestations, and as a soap substitute, among numerous other uses. Like complementary medicine in Europe, traditional medicine in Uganda is holistic, linking together body, mind, spirit, and community and giving value to a whole range of factors that not even a good general practitioner in the United Kingdom would consider.

Underlying all this are the cultural values and norms of the local people, which, combined with knowledge passed from one generation to another, give a strong sense of ownership. Sadly, their knowledge and practices are in danger of being lost, overwhelmed by the tide of "modernisation."

The fact that manufactured quinine will work in a London hospital does not mean that it will be as effective in rural Uganda. It will not work if patients do not see the need for the drug or cannot reach the health centre or if, when they arrive, the staff are away, the drugs out of stock, out of date, or counterfeit, or if the wrong dose is given or the patients do not complete the course. Despite years of health education of the community and training of health workers these are still everyday problems. At the same time I see people bypassing the plants in their garden and their grandparents' knowledge to spend a month's use time, money, and power.

The underlying assumption is that the Western way is the better one, and this implies that Western values are also superior.

Uganda has its own cultural values and norms, and despite my years here I can only claim a superficial understanding of them. As I sit in my office, people wander around the compound with no sense of urgency, greeting everyone they meet-not with a nod and a grunt but with a long exchange about their health and welfare and family. People are important and worth "wasting" time with.

Traditional medicine still forms an essential part of rural health care for most people here. Some of it is dangerous and destructive: the removal of milk teeth with a bicycle spoke as a cure for diarrhoea, or the extraction of rudimentary breast tissue for pneumonia. But much of it is good, useful, and has something to teach doctors trained in the Western model. This community, composed mainly of peasant farmers, has a wealth of knowledge about the use of plants and understanding of their medicinal uses that seems not to be confined to the traditional healers, as I had expected. People are familiar with the use of lemon and eucalyptus for coughs and colds, aloe vera for
SOUNDINGS

\section{A day in the country}

A picture window faces north east. Through the morning, skyscapes come and go: dark rain-clouds, uncertain cumulus, sudden clear blue. Far from the bustle of the city, we sit at ease. When I was a houseman, my colleague for today was our senior student: a diffident, kindly young man. I ask after his father: "A bit sore from running for a bus. Probably shouldn't have. Of course he's 92." And now we too talk of retirement.

Outside, seagulls, starlings, and sparrows appear and disappear. But we are not here for bird watching. We are examining: in the Practical Assessment of Clinical Examination Skills for the Membership of the Royal College of Physicians. The candidates appear and disappear. This morning we have history taking skills, which in some cases we have not got.

We observe, take notes, take turns to cross examine a little, and come to judgment. In some cases we disagree. Outside, seagulls, starlings, and sparrows, and the occasional blackbird, come and go. Inside, there are hawks and doves.

And this afternoon we are assessing cardiological and neurological skills, which clearly also in some cases we have not got. Clever, pleasant young doctors who have worked and studied hard forget themselves and miss things, or parade obscurities we are not interested in. We are not impressed.

The game has rules but they are not much required. When a clumsy toiler is revealed in the first minute and spends the other nine getting things wrong we do not need them. When an intuitive, informed intellect succeeds in charming both us and the patient with her skill, knowledge, and kindliness, again there is no need for rules.

The devil is in the middle. A sudden access of common sense rescues a decent doctor from the follies of the smallest print; we feel relief, but wonder if that is enough. And we may disagree again when a hitherto coherent train of clinical logic is derailed by the frankly surreal. Good and bad starts, good and bad endings: in exams or in life, which count for more?

Long ago, before I sat the exam, I learned all about Quincke's capillary pulsation, an obscure manifestation of aortic valve disease. That day in the country, I think for the first time ever, I saw it. It was - and remains - quite unimportant. But the exam is fair. Half the candidates fail.

Colin Douglas doctor and novelist, Edinburgh 